\title{
ÕPetAJA tagasiside ÕPILASE VASTUSELE ALGKOOLITUNNIS
}

\author{
Krista Strandson
}

Ülevaade. Uurimuse eesmärk on visandada õpetaja algatatud küsimussekventside struktuur ja analüüsida õpetaja tagasisidet õpilase vastusele algkoolitundides. . Analüüsi aluseks on 280 min litereeritud videosalvestust 1.-3. klassi matemaatika ja emakeele tundidest. Õpetaja tagasisidet on analüüsitud kahest vaatenurgast. Esiteks, kuidas on tagasiside seotud küsimuse sisuga: kas õpetaja tagasiside õpilase teadmisi kontrollivate küsimuste vastustele on mingil moel teistsugune kui õpilase kohta käivate küsimuste vastustele. Teiseks, missugune on tagasiside funktsioon: mil moel määrab õpetaja tagaside suhtluse edasise käigu. Analüüs näitab, et õpetaja juhib tunni kulgu äärmiselt kindlakäeliselt. Mis tahes õpilasepoolne tegevuse algatuse võimalus on minimaalne. See avaldub järgnevas. 1) Sekventsi lõpetav tagasiside on valdav sõltumata küsimuse sisust. Enamik õpetaja algatatud küsimussekventsidest moodustavad kolmikstruktuuri (küsimus-vastus-tagasiside) isegi juhul, kui õpetaja pedagoogiline eesmärk on arendada vestlust. 2) Kui õpetaja soovib sekventsi laiendada, teeb ta seda järgmise vooru sisu suunavate küsimuste abil; minimaalset vastaja jätkamist taotlevat tagasisidet, mis järgmise vooru sisu ei määratle, kasutab õpetaja väga vähe.

Võtmesõnad: vestlusanalüüs, koolitunnisuhtlus, küsimussekventsid, reaktsioon vastusele, eesti keel

\section{Sissejuhatus}

Küsimused on koolitunni vältimatu osa: õpetaja küsimused, õpilase vastused ja õpetaja tagasiside vastustele kuuluvad nii õpetamis- kui ka õppimisprotsessi juurde. Tüüpiline õpetaja esitatud küsimus moodustab koos sellele järgnevate voorudega kolmiksekventsi, mis koosneb kolmest omavahel seotud kõnevoorust: õpetaja küsimus - õpilase vastus - õpetaja tagasiside (vt nt Mehan 1985; Sinclair,

* Tööd on toetanud Eesti Teadusfond (grant nr 5685) ja riikliku programmi “Eesti keel ja rahvuslik mälu" eesti keele 
Coulthard 1975). Klassikaline kolmik on näiteks vestluskatke (1). Näite 1. reas on õpetaja küsimus, 4. reas vastama valitud õpilase vastus küsimusele ning 5 . reas õpetaja tagasiside vastusele: vastuse kinnitamine keelendiga õige. (Näidetes kasutatud eesti suulise keele transkriptsioonimärgid on esitatud kogumiku lõpus; Õ - õpetaja, pärisnimi - õpilane.)

(1) ((3. klass, matemaatika))

1. Õ: mis= ‘tuli sis `teha kui oli `korda `rohkem.

2. (...)

3. Õ: Ander.

4. Ander: korrutada.

5. Õ: õige. 'kuula ‘ülesannet.

Termini õpetaja tagasiside all on mõeldud kogu õpetaja reaktsiooni õpilase vastusele. Tagasisidevooru võib moodustada üksnes minimaalne tagasidekeelend, mis annab kõnelemise õiguse õpilasele tagasi, tähistab info vastuvõttu, annab vastusele hinnangu või kinnitab vastust; aga ka õpetaja pikem kommentaar või täpsustav küsimus vastuse kohta.

Õpetaja tagasisidevoor määrab suhtluse edasise käigu. See, kui pikalt ja kui palju õpetaja õpilasel rääkida laseb, sõltub konkreetsest pedagoogilisest eesmärgist ja kontekstist. Teoreetiliselt võiks oletada, et õpilaste kõnelemisõigus on vabam tunni osades, mille eesmärk on arendada vestlust, panna õpilasi oma arvamust avaldama, ning reglementeeritum siis, kui on keskendutud uute teadmiste omandamisele. Sellest lähtuvalt on õpetaja küsimused jagatud sisu järgi kahte rühma vastavalt sellele, kes on õige vastuse "teadja":

- õpetaja on "teadja”. Siia rühma kuuluvad õpilase teadmisi kontrollivad küsimused, mille vastust õpetaja teab;

- õpilane on “teadja”. Siia rühma kuuluvad küsimused, mille vastust õpetaja ei saa teada, näiteks küsimused õpilase arvamuse, isiku jms kohta.

Uurimuse laiem eesmärk on analüüsida sotsiaalseid suhteid klassiruumis, mil moel avaldub õpetaja ja õpilase rollijaotus keeles ja suhtluses. Käesolevas artiklis on piirdutud õpetaja tagasiside analüüsiga: kas ja kuidas erineb tagasiside teadmisi kontrollivate ja õpilase kohta käivate küsimuste vastustele, missugune on mõlemat tüüpi küsimussekventside ülesehitus.

Analüüs on kahe meetodi kombinatsioon. Analüüsi esimene etapp oli diskursusanalüütiline (Mehan 1985; Sinclair, Coulthard 1975) küsimussekventside vormi analüüs: vaatasin küsimussekventside struktuuri. See, mida üksikud struktuurikomponendid mingis kontekstis teevad ja tähendavad, jäi siin täpsemalt määratlemata. Et uurida õpetaja tagasiside funktsiooni täpsemalt, rakendasin vestlusanalüüsi metoodikat (vt näiteks Sacks 1992: 521-570; Hutchby, Wooffitt 1998: 39; Hennoste 2000a: 2236), analüüsisin iga tagasisidekeelendi funktsiooni selle reaalses kasutuskontekstis. Analüüsietapid on teineteisest sõltumatud ses mõttes, et küsimussekventside struktuuri analüüsil saadud statistikat ei ole kasutatud tagasiside funktsiooni analüüsil ja vastupidi, tagasiside funktsiooni mikroanalüüsi tulemusel saadud statistikat küsimussekventside struktuuri analüüsil. 


\section{2. Õpetaja tagasiside funktsioon}

Õpetaja tagasisidel on hulk ülesandeid. Näiteks võib see osutada, et vastus oli õige, õpetaja arvates asjakohane; viidata vastuse täpsustamise/parandamise vajadusele; õpetaja võib anda hinnangu vastusele jms. Õpetaja tagasiside määrab otseselt suhtluse edasise käigu. Dialoogi jätkamise seisukohalt jagunevad küsija tagasisidevoorud küsimuse vastusele mis tahes vestluses laias laastus kahte rühma vastavalt sellele, kas tagasiside taotleb vastaja (või kellegi teise) jätkamist või haarab tagasisidevooru sõnastaja kõnevooru endale ja algatab ise uue sekventsi.

Vastaja jätkamist taotlev tagasiside jaguneb omakorda kahte rühma: minimaalsed jätkamist taotlevad keelendid, näiteks analüüsitud koolitundides noogutus ja veel, argivestlustes $m h m h$; ning täpsustavad või parandust algatavad küsimused. Jätkaja funktsioonis lühikeste tagasisidekeelenditega osutab kuulaja, et teine pool võib oma teksti jätkata (Hennoste 200ob: 1788; Hennoste, Rääbis 2004: 134). Täpsustavad ja parandust algatavad küsimused taotlevad samuti teise poole jätkamist, kuid suunavad ja/või piiritlevad taotletava vooru sisu, nt (19), (20). Täpsustava küsimuse esitab õpetaja juhul, kui vastus on tema arvates ebapiisav või teema edasiarendamist väärt. Sekventsi lõpetava tagasiside annab õpetaja pärast õpilaselt saadud täpsustusi. Paranduse algatab õpetaja siis, kui õpilase vastus oli vale või oli selles mingil põhjusel (näiteks kuulmis- või arusaamisprobleem) midagi parandamist-täpsustamist vajavat.

Tagasisided, mis kõneleja jätkamist ei taotle, on keelendid, mis osutavad, et info on vastu võetud, et sekvents, alateema või teema on lõppenud. Erinevalt jätkajatest ei suuna nad kõnevooru eelmisele kõnelejale tagasi, tavaliselt jätkab kõnelemist vastuvõtuteate sõnastaja, näiteks algatab uue alateema või esitab uue küsimuse.

Siia rühma kuuluvad kaht liiki keelendid. Esimese rühma moodustavad lühikesed tagasisidekeelendid, info vastuvõtuteated, mis tähistavad kõige üldisemalt info vastuvõttu ja ei taotle seejuures eelmise kõneleja jätkamist. Sellised lühikesed keelendid on näiteks ahah, jah, jaa, nii, õige, hästi jne. Teise rühma kuuluvad õpetaja pikemad kommentaarid vastuse kohta. Lühikestel info vastuvõtu teadetel on hulk täpsemaid ülesandeid, mis on seotud nii konkreetse keelendi tähenduse kui ka reaalse kasutuskontekstiga. Vastuvõtuteate rollis tagasiside koolitundide analüüsis eristatud funktsioonid on järgmised.

- Neutraalne vastuvõtuteade tähistab, et info on vastu võetud, kuid ei anna saadud info kohta hinnangut (Hennoste, Rääbis 2004: 136-137). Neutraalsed vastuvõtuteated on näiteks vastuvõtukordus, partiklid jah, jaa, mhmh.

- Hinnanguline vastuvõtuteade annab lisaks info vastuvõtmise tähistamisele vastuse kohta hinnangu, näiteks tore, tubli, vahva, kurb, ilus, kena, oi jt.

- Vastuvõtuteade, mis tähistab informeerituse muutust näitab, et eelnev info oli uus, et kuulaja on selle vastu võtnud ja sellest aru saanud (Hennoste 200ob: 1780; Keevallik 2003: 38). Vormiliselt on selles tähenduses tavaliselt partikkel ahah, selle variant ahaa ning kahest eelmisest mõnevõrra erineva tähendusega $a a$. Ka informeerituse muutusele osutavad partiklid on ses mõttes neutraalsed vastuvõtuteated, et need ei anna 
vastusele hinnangut, vaid tähistavad, et info vastuvõtja käsitleb saadud infot enda jaoks uuena või vähemalt soovib nii näidata.

- Kinnitavat vastuvõtuteadet kasutatakse koolitundides väga sageli, vormiliselt võib kinnituse ülesannet täita vastuvõtukordus; keelendid jah, jaa, mhmh, just, õige ning hinnangulised keelendid kena, hästi, hea jt.

- Piiritleja osutab nagu teisedki info vastuvõtu teated, et info on vastu võetud ja sekvents, teema või alateema lõppenud, kuid tähistab sekventsi piire tugevamalt kui hinnanguline ja neutraalne vastuvõtuteade (Hennoste, Rääbis 2004: 136-137). Piiritleja funktsioonis võivad olla näiteks keelendid nii, kena ja tänusõnad aitäh, tänan.

Kõigile tagasisidedele leiduvad hinnangulised paarikud (Hennoste, Rääbis 2004: 132). Hinnanguline variant esines käesoleva analüüsi järgi nii kinnitaval kui neutraalsel vastuvõtuteatel. Analüüsitud materjal ei sisaldanud ühtegi hinnangulise jätkaja rollis tagasisidet, kuigi teoreetiliselt on see võimalus olemas; piiritleva tagasiside hinnangulised variandid kuuluvad hinnanguliste vastuvõtuteadete rühma.

Kommentaarid vastuse kohta võivad lisanduda igale tagasisidekeelendile: nad seletavad, täpsustavad, laiendavad jms saadud vastust või annavad vastuse kohta pikema hinnangu. Järgmises näites täpsustab ja laiendab õpetaja Siimult saadud õiget vastust reas 3 .

(2) ((1. klass, eesti keel))

1. Õ: ja mis=te arvate `miks ma panen kaks tooli klassi ette.

2. Siim: jutustajaid sab kaks tükki kes tulevad `lugema.

3. Õ: ‘väga õige. ja nemad on sis Žanna ja ja Fe:liks.

Õpetaja tagasiside funktsiooni analüüsitud korpuses võtavad kokku tabelid 1 ja 2.

Tabel 1. Tagasiside, mis ei taotle eelmise kõneleja jätkamist

\begin{tabular}{|l|c|c|}
\hline \multirow{2}{*}{ Tagasiside tüüp } & \multicolumn{2}{|c|}{ Õpetaja küsimus } \\
\cline { 2 - 3 } & Õpetaja on "teadja” & Õpilane on “teadja” \\
\hline Kinnitus & 44 & \\
(väga) õige & 1 & \\
õigus & 1 & \\
seda ka & 1 & \\
olen nõus & 19 & \\
\hline Kinnitus/hinnang & 4 & \\
(väga) tubli (oled) & 4 & \\
(väga) hästi & 3 & \\
(väga) kena & 1 & \\
väga hea & 10 & \\
väga tore & & \\
\hline Hinnang & & \\
(väga) tubli & & \\
(väga) tore & & \\
väga vahva & & \\
(väga) hästi & &
\end{tabular}




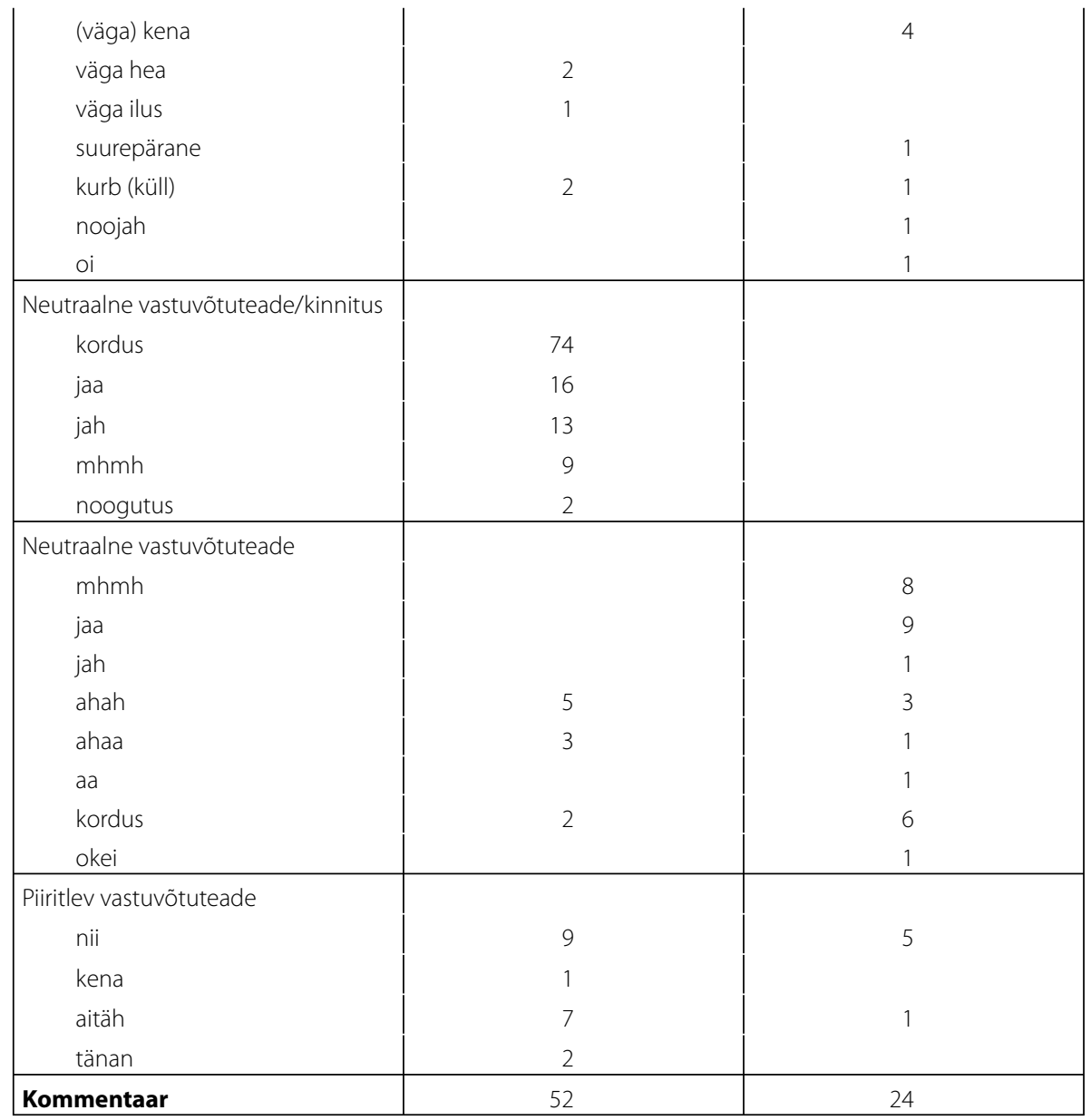

Tabel 2. Eelmise kõneleja jätkamist taotlev tagasiside

\begin{tabular}{|l|c|c|}
\hline \multirow{2}{*}{ Tagasiside tüüp } & \multicolumn{2}{|c|}{ Õpetaja küsimus } \\
\cline { 2 - 3 } & Õpetaja on “teadja” & Õpilane on “teadja” \\
\hline $\begin{array}{l}\text { Jätkaja } \\
\text { noogutus } \\
\text { veel }\end{array}$ & 5 & 1 \\
\hline $\begin{array}{l}\text { Kinnitus/jätkaja } \\
\text { jaa } \\
\text { kordus }\end{array}$ & 11 & \\
\hline Täpsustav küsimus & 3 & \\
\hline Parandusalgatus & 79 & 35 \\
\hline
\end{tabular}

Tagasiside funktsionaalsete alarühmade pïrid ei ole alati selged: üks ja sama keelend võib korraga täita mitut ülesannet. See, missugus(t)es funktsiooni(de)s konkreetne keelend esineb, selgub ainult kasutuskonteksti analüüsides. Siin on oluline küsimuse 
sisu: kas tegemist on teadmisi kontrolliva küsimusega või küsimusega õpilase kohta. Teadmisi kontrollivatele küsimuste õigete vastuste reaktsioonivoorudele kaldub sageli lisanduma kinnituse lisatähendus, mis võib haakuda kas hinnangulisele vastuvõtuteatele (tubli, tore, hästi, kena) või neutraalsele info vastuvõtuteatele (vastuvõtukordusele, partiklitele jah, jaa, $\mathrm{mhmh}$ ). Näiteks reaktsioonina õpilase kohta käiva küsimuse vastusele on jah, jaa ja mhmh neutraalse vastuvõtuteate funktsioonis, kuna õpetaja ei tea "õiget” vastust ega saa seda ka kinnitada või ümber lükata. Seevastu reaktsioonina õpilase teadmisi kontrolliva küsimuse vastusele on keelenditel jah, jaa ja mhmh kinnituse lisatähendus. Ainus tagasisidekeelendite rühm, mis õpilase jätkamist ei taotle ja millele kinnituse tähendust teadmisi kontrolliva küsimuse vastusele reageerides ei lisandu, on informeerituse muutusele osutavad vastuvõtuteated ahah, ahaa ja aa. Ka piiritlejale võib juhul, kui ta esineb tagasisidena teadmisi kontrollivale küsimusele, implitsiitselt lisanduda kinnituse tähendus. Kuna piiritleja esmane funktsioon on osutada sekventsi piiridele, ei ole käesolevas analüüsis kinnituse lisatähendusega piiritlejaid eristatud.

Järgnevalt on analüüsitud kumbagi tagasisidekeelendite rühma eraldi kahes kasutuskontekstis: tagasisidena õpilase teadmisi kontrollivatele küsimustele ja õpilase kohta käivatele küsimustele.

\section{Tagasiside, mis eelmise kõneleja jätkamist ei taotle}

\subsection{Kinnitus}

Kinnitus järgneb õpilase teadmisi kontrolliva küsimuse vastusele juhul, kui vastus oli õige ja õpetaja arvates asjakohane. Õpetaja kasutas õpilase vastuse kinnitamiseks järgmisi vahendeid:

- keelendeid õigus, (väga) õige, seda ka;

- keelendeid (väga) tubli, (väga) hästi, (väga) hea, (väga) kena, (väga) tore;

- õpilase vastuse täpset, osalist või modifitseeritud kordust;

- partikleid jah,jaa, mhmh;

- noogutust.

Vastuse kordus on kõige sagedasem vastuse kinnitamise vahend (74 juhul 192-st); sageduselt järgnevad keelend õige (44 juhtu), kinnitava lisatähendusega tubli (19 juhtu), partiklid jaa (16 juhtu) ja jah (13 juhtu). Kordusega kinnituse sage kasutus ei ole kindlasti mitte juhuslik. Esiteks võib korduste suur osakaal õpetaja kõnes tuleneda lastega suhtlemise eripärast. Teiseks võimaldavad kordused olulist infot veelkord kogu klassi jaoks kuuldavaks teha, et garanteerida õige vastuse jõudmist võimalikult paljude õpilasteni.

Kui heita pilk tabelisse 1, siis on esiteks näha, et kinnitada saab vaid teadmisi kontrolliva küsimuse vastust; ning teiseks: ainult kinnitavas tähenduses kasutas õpetaja keelendeid õigus, (väga) õige, seda ka ja olen nõus. Keelenditel õige ja õigus on kõige "tugevam" kinnitav tähendus. Neid keelendeid kasutas õpetaja ainult õpilase teadmisi kontrolliva küsimuse õigele vastusele reageerides, nagu näites (3). 
(3) ((3. klass, matemaatika))

1. Õ: * 'kaheksa `teist jagatud `kahega. * Vaike?

2. Vaike: öheksa.

3. Õ: õige?

Ülejäänud keelendid, mida õpetaja vastuse kinnitamiseks kasutas, on olemuselt mitmetähenduslikud, nende tegelik tähendus selgub alles kontekstis. Näiteks keelendil tubli on teadmisi kontrolliva küsimuse korral lisaks hinnangu andmisele ka kinnituse lisatähendus, kuid reaktsioonina õpilase kohta käiva küsimuse vastusele tublil kinnitav tähendus puudub, vrd (4) ja (5).

(4) ((3. klass, matemaatika))

1. Õ: `mis=oli `korrutis ja `mis=olid `tegurid, `tuleta `meelde? (...)

2. `viis`teist. (...)`millised tegurid on?

3. Liis: ` kolm=korda=viis.

4. Õ: tubli?

(5) (1. klass, õpetaja jagas lastele paberilipikud, kuhu oli kirjutatud elusorganismide klassid. Lapsed pidid mõtelema, mis liigi esindaja nad tahaksid olla ja miks)

1. Õ: `kellel=on `valmis, [`Amaalia] `palun.

2. L?: [`mina tahan]

3. (.)

4. Amaalia: kui kui=ma `oleksin `loom (.) [sis=ma `oleksin] e `valge 'hobune?

5. Õ:

6. Õ: * miks. *

$\left[>{ }^{*}\right.$ `Mait=tule `siia. $\left.{ }^{*}<\right]$

7. (.)

8. Amaalia: `sellepärast mulle=`meeldivad ä `hästi `hobused?

9. Õ: tubli.

Näites (4) esitab õpetaja teadmisi kontrolliva küsimuse, mille eesmärk on, et õpilane ütleks arvu viisteist tegurid. Õpetaja saab Liisilt dialoogi 3. reas õige vastuse ning kinnitab seda keelendiga tubli. Poisitiivne hinnang täidab ka vastuse kinnitamise rolli.

Näites (5) reageerib õpetaja sama keelendiga õpilase kohta käiva küsimuse mis loom, lind või taim sa tahaksid olla vastusele. Õpetaja ei saa vastust kinnitada, kuna ta ei tea õiget vastust: selle näite tubli-l saab olla ainult hinnangu tähendus.

Vastuvõtukordus ja partiklid jah,jaa, mhmh võivad samuti sõltuvalt eelnenud küsimuse sisust olla kas vastuse kinnitajad, nagu $\mathrm{mhmh}$ näites (6), või neutraalsed info vastuvõtu teated (8).

(6) ((3. klass, matemaatika))

1. Õ: ee `kuus jagatud `kahega.

2. (...) ((lapsed tõstavad kätt, õpetaja osutab Gerlile))

3. Gerli: kolm.

4. Õ: $\mathbf{m h m h}$

5. (.) ((Gerli istub)) 


\subsection{Hinnang}

Hinnangulised vastuvõtuteated, mida õpetaja kasutas, olid järgnevad: väga tubli, väga tore, väga vahva, väga hästi, väga kena, väga hea, väga ilus, suurepärane, oi, noojah, kurb küll. Kõik, välja arvatud loetelus viimased, noojah ja kurb küll, annavad positiivse hinnangu. Juhul kui õpetaja sai vale vastuse või ei jäänud vastusega rahule, algatas ta pea alati paranduse, andes probleemse vastuse sõnastajale või mõnele teisele õpilasele võimaluse vastus uuesti öelda. Hinnanguline tagasiside võib järgneda nii teadmisi kontrollivate küsimuste kui ka õpilase kohta käivate küsimuste vastustele.

Õpilase kohta käiva küsimuse vastusele reageerides ei lisandunud hinnangule ühelgi juhul kinnituse tähendust, see tuleneb juba küsimuse sisust: õpetaja ei saa kinnitada ega kummutada infot, mida ta ise varem ei teadnud (5).

Teadmisi kontrolliva küsimuse vastusele reageerides olid hinnangulisel keelendil järgmised tähendused ja positsioonid tagasisidevoorus.

- Keelenditele väga tubli, väga hästi, väga kena ja väga tore võib teadmisi kontrolliva küsimuse vastusele reageerides lisanduda kinnituse tähendus. Sellisel juhul esines hinnanguline keelend reaktsioonivoorus üksi, positiivse hinnanguga keelend kinnitas ühtlasi ka saadud vastuse õigeks (4).

- Hinnanguline tagasiside võis moodustada tagasisidevooru koos vastust kinnitava ja/või piiritleva tagasisidega (7). Sellisel juhul hinnangulisele tagasisidele kinnituse tähendust ei lisandu, kuna vastuse õigsust kinnitav keelend on tagasisidevoorus juba olemas, nagu näites neli muidugi 3 . reas.

(7) ((3. klass, matemaatika))

1. Õ: * ‘kaheksa jagatud `kahega. * ((õpetaja vaatab Karolini poole))

2. Karolin: neli.

3. Õ: neli, muidugi. (.) ((Karolin istub)) aitäh, (.) tubli.

\subsection{Neutraalne vastuvõtuteade}

Neutraalse vastuvõtuteatega osutab info vastuvõtja, et info on vastu võetud, kuid ei anna saadud info kohta hinnangut. Neutraalsed vastuvõtuteated olid vaadeldud materjalis vastuvõtukordus; partiklid jah, jaa, mhmh, okei ning informeerituse muutusele osutavad partiklid ahah, ahaa ja aa. Tähenduselt jagunevad need partiklid kaheks: partiklid jah, jaa, mhmh ning vastuvõtukordus sobivad ka vastuse kinnitamiseks ja samameelsuse osutamiseks; ahah, ahaa ja aa aga tähistavad saadud info uudseks, kinnituse lisatähendus neil puudub. Teoreetiliselt võiks oletada, et koolitundides kasutab õpetaja neutraalset vastuvõtuteadet juhul, kui ta reageerib õpilase kohta käiva küsimuse vastusele, kuna sellist vastust ei saa kinnitada ega kummutada. Jällegi võiks öelda, et nii kaldus olema, kuid ei olnud alati. Tõepoolest, enamik ainult vastuvõtuteate funktsioonis keelendeid esines tagasisidena õpilase kohta käivatele küsimustele (41-st 30). Kuid ülejäänud 11 juhtu olid reaktsioonid teadmisi kontrollivatele küsimustele. Nüüd jõuame järgmiste küsimusteni. Millal ja miks kasutas õpetaja teadmisi kontrollivale küsimusele reageerides neutraalset vastuvõtuteadet, andmata vastuse õigsuse/sobivuse kohta omapoolset hinnangut? 
Missugust pedagoogilist ja/või suhtluslikku eesmärki neutraalne vastuvõtuteade teadmisi kontrollivate küsimuste puhul täidab? Tabelit 1 jälgides näeme 10 sellist näidet, kus õpetaja reageeris õpilase teadmisi kontrollivale küsimusele neutraalse vastuvõtuteate rollis tagasisidekeelendiga; konkreetsemalt: 8 korral info uudsusele osutavate partiklitega ahah ja ahaa ning kahel korral vastuvõtukordusega.

Neid numbreid vaadates tekib kohe kaks tähelepanekut. Esiteks: info uudsusele osutav partikkel ahah ja selle variant ahaa ning partikkel aa on koolitunnis äärmiselt haruldased - kogu analüüsitud korpuses leidus vaid 13 kasutusjuhtu, neist 8 reaktsioonina teadmisi kontrolliva küsimuse vastusele ja 5 õpilase kohta käiva küsimuse vastusele. Info uudsusele osutavate partiklite harv kasutus reaktsioonina teadmisi kontrollivatele küsimustele on teoreetiliselt loogiline: õpetaja teab ju õiget vastust oma esitatud küsimusele, vastuses ei saa olla tema jaoks uut informatsiooni. Õpilase kohta käivate küsimuste vastust aga õpetaja ei saa teada, järelikult saab ta vastustega enda jaoks uut informatsiooni. Huvitav on, et analüüsitud korpuses leidus info uudsusele osutavat partiklit ahah või selle variante reaktsioonina õpilase kohta käivatele küsimustele veelgi vähem kui reaktsioonina teadmisi kontrollivatele küsimustele. Siinkohal on hea võrdlusmaterjal Tiit Hennoste statistika dialoogipartiklite kasutusest argi- ja ametlikes vestlustes (ametlike vestluste korpuses ei olnud ühtki koolitundi), mille järgi moodustas ahah ametliku keele korpuses 3,9\% sõnavormidest, argikorpuses aga 1,3\%. Partikkel a moodustas ametliku keele korpuses 0,9\% ja argikorpuses 2,1\% sõnavormidest (Hennoste 200ob: 1780). Käesoleva uurimuse aluseks olnud koolitundide korpuses olid vastavad arvud järgmised: $a h a h$ ja ahaa moodustasid mõlemad 0,03\% sõnavormidest, a a 0,004\% sõnavormidest. Samalaadseid tulemusi on saanud John Heritage, kes pani tähele, et inglise keele informeerituse muutust väljendav tagasiside oh puudub regulaarselt sellistes institutsionaalsetes suhtlusregistrites nagu kool, kohus, raadio- ja teleuudised. Põhjuseks arvab ta olevat selle, et küsijad (õpetajad, kohtunikud, intervjueerijad) teavad või aimavad vastust, seega ei saa vastus olla küsija jaoks uudne (Drew ja Heritage 1992: 41).

Järgnevalt analüüsime neutraalse vastuvõtuteate funktsioonis olevate tagasisidepartiklite kasutust eraldi kahes kontekstis: tagasisidena teadmisi kontrolliva küsimuse vastusele ning õpilase kohta käiva küsimuse vastusele.

\section{- Küsimus õpilase kohta}

Vaatleme kõigepealt neutraalse vastuvõtuteate teoreetiliselt kõige loogilisemat ning ka statistiliselt kõige sagedasemat kasutuskonteksti: tagasisidena õpilase kohta käivale küsimusele. Selles kontekstis kasutas õpetaja vastuvõtukordust ja partikleid mhmh,jaa,jah, okei, ahah, ahaa, aa. Kõige sagedamini kasutatavad partiklid olid jaa (9 juhtu), mhmh (8 juhtu) ja vastuvõtukordus (6 juhtu). Partiklit jah kasutas õpetaja neutraalse vastuvõtuteatena vaid 1 korral, ülejäänud $13 j a h$-i esinesid kontekstis, kus neile lisandus kinnituse tähendus. See annab alust oletuseks, justkui oleks jah "tugevam kinnitaja” kui jaa, kuna vastuvõtuteate funktsioonis kasutati enamasti jaa-d. Mingisugust konkreetsemat järeldust ei ole analüüsitud materjali põhjal võimalik teha, eriti kui arvestada asjaoluga, et suurem osa vastuvõtuteate rollis olnud jaa-dest olid positsioonis, kus õpetaja küsis ühte ja sama küsimust järjest mitmelt õpilaselt ning jaa tähistas ühtlasi üleminekut ühe õpilase küsitlemiselt teise õpilase küsitlemisele. Ka Riina Kasterpalu uurimus partiklite jah, jaa ning jajaa 
kasutamisest müügivestlustes näitab muu hulgas, et vastust pakkuva küsimuse kinnitamiseks kasutatakse ülekaalukalt jah-i, jaa-d oluliselt vähem (Kasterpalu 2005: 999). Info uudsusele osutavaid partikleid ahah, ahaa ja aa, millele kinnituse tähendust ei ole võimalik lisada, kasutas õpetaja neutraalse vastuvõtuteatena õpilase kohta käiva küsimuse vastusele reageerides 5 korral.

Näide (8) illustreerib neutraalse vastuvõtuteate funktsioonis partikli $\mathrm{mhmh}$ kasutust.

(8) ((1. klass; õpetaja jagas lastele paberilipikud, kuhu oli kirjutatud elusorganismide klassid. Lapsed pidid mõtlema, mis liigi esindaja nad tahaksid olla ja miks))

1. Õ: ee (.) Aune?

2. (...)

3. Aune: $\left\{{ }^{*}\right.$ aga kui ma oleks=lind $\left.{ }^{*}\right\}$ siis `mina `tahaksin olla `luik.

4. (...)

5. Õ: miks='luik.

6. (.)

7. Aune: mulle=`meeldivad `luiged.

8. (.)

9. Õ: * $\mathbf{m h m h}{ }^{*}() `$.$T Tiit `Treial.$

Näites (8) reageerib õpetaja õpilase 3. ja 7. reas sõnastatud vastusele minimaalse neutraalse vastuvõtuteatega $\mathrm{mhmh}$, mis lõpetab ühtlasi sekventsi, ning õpetaja palub samale küsimusele vastata järgmisel õpilasel.

\section{- Teadmisi kontrolliv küsimus}

Teoreetiliselt võiks eeldada, et teadmisi kontrolliva küsimuse vastusele reageerib õpetaja kinnitava tagasisidega, mitte neutraalse vastuvõtuteatega. Nii ka enamasti oli, kuid mitte alati: korpuses leidub 10 juhtu, kus õpetaja reageerib teadmisi kontrolliva küsimuse vastusele neutraalse vastuvõtuteatega; 2 juhul vastuse kordusega ja 8 juhul partikliga ahah või ahaa. Näited, kus õpetaja kasutas neutraalset vastuvõtuteadet teadmisi kontrollivatele küsimustele reageerides, on põnev analüüsimaterjal ning peegeldavad ilmekalt, kuidas suhtlus ja pedagoogika kokku saavad.

Nüüd jõuame juba eespool esitatud küsimusteni: millal ja miks kasutas õpetaja teadmisi kontrollivale küsimusele reageerides neutraalset vastuvõtuteadet, andmata vastuse õigsuse/sobivuse kohta hinnangut? Missugust pedagoogilist ja/või suhtluslikku eesmärki neutraalne tagasiside teadmisi kontrollivate küsimuste puhul täidab?

Vaatame esmalt vastuvõtuteate funktsioonis korduse näidet.

(9) ((1. klass, eesti keel, õpetaja palus lastel valida laualt pildid äsja loetud jutustuse tegelastest))

1. Õ: kes=se `on. ((kummardub Andrease kohale))

2. Andreas: siil

3. Õ: siil. kas `oli `tänases jutus `siil.

4. L-d: e:i

5. Õ: e:i `olnud. `pane=se `lauale tagasi. 
Andreas valis ekslikult pildi loomaga, kellest jutustuses ei räägitud. Tema vastus on üldises plaanis õige, õpetaja reageerib sellele kordusega ning algatab seejärel kohe paranduse, mille viib läbi kogu klass. Õpetaja kordus 3. reas on pigem vastuvõtuteate kui kinnituse rollis.

Info uudsusele osutavatest partiklitest kasutas õpetaja teadmisi kontrollivate küsimuste vastustele reageerides partikleid ahah ja ahaa.

Analüüsitud materjalis esines nendel partiklitel kaks kasutuskonteksti.

- Õpilase vastus oli õige, õpetaja reageeris õigele vastusele partikliga ahah või ahaa, kuid sel juhul eelnes või järgnes info vastuvõtupartiklile muu kinnitav ja/või hinnanguline tagasisidekeelend (näide 10).

(10) ((1. klass, matemaatika, õpetaja luges lastele ette muinasjutu kolmest karust ja küsis seejärel, mida jutus oli kolm))

1. Õ: `Kertu, mis=`sina arvad.

2. Kertu: kausse.

3. (.)

4. Õ: 'kausse=oli kolm. ahaa. (...) mis=`sina=`Mart arvad.

Näites (10) valib õpetaja vastama Kertu küsimusega mis sina arvad: selline küsimuse sõnastus osutab, justkui oleks küsimus tõesti õpilase arvamuse kohta, kuigi tegelikult on küsimus teadmiste kontroll. Seepeale saab õpetaja Kertult dialoogi reas 2 õige vastuse kausse ning kinnitab seda laiendatud kordusega: kausse oli kolm ning lisab kordusele uue info vastuvõttu tähistava partikli ahaa. Siinkohal on võimalik tõlgendus, et õpetaja justkui jätkab “tõeliste”, s.t argivestluses esinevate küsimussekventside formaati ning annab ka vastava tagsiside: osutab ahaa-ga, et info oli tema jaoks uus. Samas on info uudsuse osutusele eelnenud erinevalt näiteks tõelistelt uut infot taotlevatest küsimussekventsidest vastuse õigsuse kinnitus.

Teine võimalus on tõlgendada õpetaja laiendatud kordust reas 4 vastuvõtukordusena, mitte kinnitusena. Sel juhul registreerib õpetaja Kertu vastuse, kuid ei ütle, kas see oli õige või vale, ning lisab informeerituse muutust tähistava partikli ahaa. Ka sel juhul kasutab õpetaja n-ö petustrateegiat, reageerides teadmisi kontrolliva küsimuse õigele vastusele neutraalse info uudsusele osutava vastuvõtuteatega, et julgustada järgmist õpilast vastama.

- Õpetaja kasutas info uudsusele osutavaid partikleid ka siis, kui õpilase vastus ei vastanud õpetaja ootustele, näiteks ei olnud kooskõlas õpetaja pedagoogiliste eesmärkidega. Sellisel juhul järgneb “tugevam”, kinnitav tagasisidekeelend alles pärast soovitud vastuse saamist.

Vaatame näiteks katket esimese klassi matemaatikatunnist.

(11) ((1 klass, matemaatika, õpetaja luges lastele muinasjuttu kolmest karust))

1. Õ: aga =`mis `õpetuse $=$ me `võiks Mašale `öelda. `mida $=$ ei `tohiks teha.

2. (...)

3. Ander: $m a={ }^{\prime}$ tean?=

4. Õ:=mis=ta `valesti tegi. (...) mis=sa `arvad.

5. (...) ((osa lapsi tõstab kätt))

6. Õ: Andreas. 
7. Andreas: et ta `karu `majja läks.

8. (.)

9. Õ: aha:h aga `ENNE seda.

10. Mait: mm ((tõstab kätt))

11. (...)

12. Õ: noo?

13. Mait: ee=et ta `ära eksis. (...) ja `üks oli `ka:=vel=et (...) ee et

`kõige=lõpus on=ju `see 14. ka: kui=ta (...) $\{$ hullem=et=ta $\} `$ putru panid.

15. Õ: [ahah]

16. Mait: ['karud] ei 'teinud talle `midagi.

17. Õ: $\mathbf{e i}=\mathbf{e i}=\mathbf{n e i d}$ 'karusid=tea $=$ 'midagi $=$ aga mis=te `veel `mina ütleks et 'ENNE seda $>18$. kui=ta `karude juurde jõudis $<$ `mis=ta `valesti 'tegi.

19. (...)

20. Riivo: $\{-\}$.

21. Õ: seda 'ka:.

22. (...) ((Heli tõstab kätt))

23. Õ: Heli.

24. Heli: ta ronis `aknast `välja.

25. (.)

26. $\tilde{O}: \mathbf{e i}=$ 'noh ta pidi ‘põgenema $=>$ sest ega=neid `karusid

ei=`tea. aga $=\mathrm{ma}=$ `arvan=et 27. `üksi kas `tohib `väike [`laps `metsa 'minna.]

28. Andrus:

[mul=on `valmis $]$

((Andrus tõstab kätt))

29. L-d: e:i

30. (.)

31. Õ: < va:t `õi:ge. >

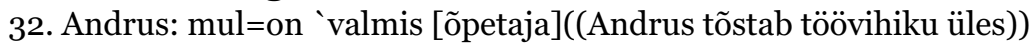

33. Õ: [`metsa]’läheme `ikkagi `koos `ema=või

`isaga aga `mitte `üksi 34. `päini.

35. Triinu: = või `vanaemaga.

36. Õ: `vä:ga `õige.

Reas 1 esitab õpetaja küsimuse, millel on ilmne eesmärk teha loetud muinasjutust õpetlik järeldus. Seejärel saab ta mitu sisuliselt võimalikku õiget vastust: et ta karu majja läks (rida 7), et ta ära eksis (rida 13), ta ronis aknast välja (rida 24). Need vastused ei ühti aga õpetaja ideega soovitud vastusest, see peegeldub selgelt õpetaja reaktsioonivoorude ehituses: vastuvõtuteade ahah+täpsustav küsimus (rida 9), vastuvõtuteade ahah pealerääkimisena (rida 15), kommentaar +täpsustav küsimus (read 17-18), distantseeruv kinnitus seda ka (rida 21), kommentaar+täpsustav küsimus (read 26-27). Kui õpilased soovitud vastuseni ei jõua, muutuvad ka küsimuste vorm ja/või sisu täpsemaks; viimane küsimus, millele lõpuks soovitud vastus tuleb, on suletud kas-küsimuse vormis: üksi kas väike laps tohib metsa minna. Näitest on näha, et tagasiside kinnituse "tugevus" on astmeline. Õpetaja reageerib voorudele, mis on küll õiged, kuid ei ole sisult sellised, mida tema vastuseks ootas, vastuvõtuteatega ahah, distantseeruva kinnitusega seda $\mathrm{ka}$, kommentaaridega. Alles pärast iseenda sõnastatud suletud kas-küsimusele (rida 27) saadud vastust 
kasutab ta "tugevamat" kinnitavat keelendit vat õige ja ülirõhutatud kinnitust väga õige, reageerides Triinu 35. reas lisatud täpsustusele.

\subsection{Piiritleja}

Piiritleja osutab nagu vastuvõtuteadegi, et info on vastu võetud ja sekvents, teema või alateema on lõppenud, kuid tähistab sekventsi piire tugevamalt. Piiritleja funktsioonis võivad olla näiteks keelendid nï, kena ja tänusõnad aitäh, tänan. Tänusõnad aitäh ja tänan ning piiritlev keelend kena paiknesid alati sekventsi lõpus. Partikkel nii esines nii alasekventsi piiril, enne täpsustavat küsimust kui küsimussekventsi lõpus. Tegelikult, üldisemalt võttes, on piiritlev funktsioon kõigil õpetaja tagasisidevahenditel, mis õpilase jätkamist ei taotle. Prototüüpne piiritlev tagasiside on näiteks kena näites (12) real 3.

(12 ) ((3. klass, matemaatika, tekstülesande lahendamine))

1. Õ: ja=`mis oleks sis `vastus.

2. Epp: $\{$ kolm $\}$

3. Õ: ‘kolm=nööpi=sest < `kuuele (.) `kleidile (.) `õmmeldi. > (...) ee

'kena. (.) `pane=oma 4. (.) ee (...)* ei `pane `kaa *

5. L-d: hehehe

6. Õ: `õpikust `ülesanne `kaks=sada=`öheksa teeme `kirjalikult 'vihikusse

Ka partiklil nii on eesti keeles piiritlev funktsioon. Renate Pajusalu on nïd analüüsinud kui teema algatajat ja lõpetajat raadiointervjuudes (Pajusalu 1999: 71), Leelo Keevallik üldisemalt kui piiritlejat, mis tähistab üleminekut ühest (suhtluslikust) tegevusest teise (Keevallik 2000: 350-351). Käesoleva uurimuse raamistikus on nii piiritlev vastuvõtuteade.

Kinnituse lisatähendus võib nii-le lisanduda implitsiitselt juhul, kui ta on reaktsioon õpilase teadmisi kontrolliva küsimuse vastusele (vrd all esitatud näiteid (13) ja (14))

(13) ((3. klass, eesti keel, õpetaja küsis, mis vahe on tontidel ja haldjatel))

1. Õ: Paul?

2. Paul: ‘tondid on nagu: $\mathrm{mm}$ rohkem e `kurjemad ja `haldjad on `head.

3. Õ: nii, palun? ((õpetaja vaatab Peebu poole))

(14) ((3. klass matemaatika; õpetaja ütleb arvu, õpilased peavad ütlema selle tegurid ))

1. Õ: 'kakskümmend= ‘üks.

2. (( lapsed tõstavad kätt, õpetaja noogutab Katrele))

3. Katre: `kolm=korda=`seitse.

4. Õ: * nii. * 'kakskümmend=`neli.

Mõlemas näites on õpetaja tagasisidekeelend nii täpselt ühesuguses sekventsiaalses positsioonis. Erinev on vaid see, et näites (13) küsib õpetaja õpilase arvamuse kohta, näite (14) küsimus kontrollib aga õpilase teadmisi. Mõlema näite nii-l on ühesugune ülesanne: osutada küsimussekventsi lõpule, mõlemal juhul algatab õpetaja pärast nï-d uue küsimussekventsi. Kuna näite (14) puhul on tegemist 
õpilase teadmisi kontrolliva küsimusega, lisandub nü-le implitsiitselt vastuse kinnitamise roll.

Ülejäänud nii kasutuskontekstid olid kahest eelmisest näitest mõnevõrra erinevad, õpetaja kasutas nii-d tagasisidena nii teadmisi kontrolliva kui õpilase kohta käiva küsimuse vastusele siis, kui ta soovis saadud vastust täpsustada, nagu näites (15). Selline nii kasutuskontekst on võrreldav neutraalse vastuvõtuteate kasutamisega tagasisidena teadmisi kontrolliva küsimuse vastusele, vrd (9) ja (11). Õpetaja saab õpilaselt vastuse, mis ei vasta mingil põhjusel tema ootustele, kuid mis ei pruugi olla põhimõtteliselt vale; ning annab tagasiside, millel kinnituse tähendus puudub või ei ole selgepiiriline; ning algatab vastuse täpsustamise. Pärast eeldatud vastuse saamist reageerib õpetaja “tugevama” kinnitava keelendiga.

(15) ((1. klass, eesti keel))

1. Õ: ‘miks Anna `nuttis.

2. (...) ((osa lapsi tõstab käe))

3. Õ: ee `Mait.

4. Mait:et: ta=i leidnud 'koduteed.

5. Õ: nii. mis=sis `Annaga oli `juhtunud.

6. (...)

7. Ô: `mis `oli `Annaga `juhtunud.

8. (...)

9. Õ: `Mariliis.

10. Mariliis: \{ta eksis `ära. $\}$

11. Õ: õige.

Õpetaja luges lastele ette jutukese Annast, kes suures linnas ära eksis, ja küsib nüüd jutus toimunu kohta. Reas 1 esitab õpetaja küsimuse miks Anna nuttis ning saab sellele Maidult põhimõtteliselt õige vastuse: $t a=i$ leidnud koduteed. Seepeale alustab õpetaja oma vooru partikliga nii ning esitab täpsustava küsimuse ja valib uue vastaja, Mariliisi, kes sõnastab täpsustuse ta eksis ära, millele õpetaja reageerib tugevalt kinnitava keelendiga õige. Keelendil nii 5 . reas on vähemalt kaks ülesannet: esiteks on ta piiritlev vastuvõtuteade, mis viitab, et alasekvents on lõppenud ja eelmises voorus sisaldunud info on vastu võetud. Teiseks, kuna tegamist on teadmisi kontrolliva küsimusega, lisandub implitsiitselt kinnitav lisatähendus, mis ei ole siiski nii tugev ja selge kui 11. real sõnastatud tagasisidel õige.

Kui jälgida nii intonatsiooni, siis küsimussekventsi lõpus oli nii hääldatud alati langeva intonatsiooniga (14). Kui õpetaja soovis vastust mingil põhjusel täpsustada või palus samale küsimusele vastata mitmel õpilasel, kasutas ta enne täpsustava küsimuse esitamist või uue vastaja valikut nii langeva kui poollangeva intonatsiooniga nü-d (13), (15).

\section{Eelmise kõneleja jätkamist taotlevad tagasisided}

Omaette rühma moodustavad õpilase jätkamist taotlevad õpetaja tagasisidekeelendid. Nendel keelenditel puudub piiritlev funktsioon, nad annavad kõnevooru tagasi õpilasele, kuid määratlevad õpilase järgmise kõnevooru sisu erinevas ulatuses. Minimaalsed jätkamist taotlevad keelendid (materjalis jaa, nii, veel, kordus, noogutus) jätavad järgmise vooru sisu täielikult õpilase otsustada (küsimussekventsi puhul 
määrab sisu muidugi eespool esitatud küsimus). Teine võimalus on, et õpetaja esitab saadud vastuse kohta täpsustava küsimuse, et teemat edasi arendada või algatab paranduse, kui õpilase vastus oli tema jaoks mingil põhjusel probleemne. Tabelist 2 saab teha kolm olulist üldistust.

- Õpetaja kasutas minimaalset jätkajat, mis järgmise vooru sisu kuidagi ei määratle, äärmiselt vähe (20 juhul). Kui õpetaja soovis, et õpilane vastamist jätkaks, esitas ta täpsustava küsimuse (114 juhul). Juhul kui vastus oli mingil põhjusel probleemne, algatas õpetaja parandussekventsi (67 juhul).

- Õpetaja ei kasutanud argivestlustes ja muud tüüpi ametivestlustes jätkaja funktsioonis tavaliselt kasutatavat partiklit $m h m h$ jätkajana kogu korpuses mitte ühtegi korda. Kõik korpuses leidunud $m h m h$-id olid kas vastuvõtuteate või kinnituse rollis. Siinkohal on hea võrdlusmaterjal Tiit Hennoste statistika, mille järgi moodustas mhmh ametliku suhtluse korpuses (ei sisalda koolitunde) 9,7\% sõnavormidest ja argikeele korpuses $6,2 \%$ sõnavormidest (Hennoste 200ob: 1780). Analüüsitavas koolitundide korpuses moodustab $m h m h$ o,o8\% sõnavormidest.

Korpuses leidus üks huvitav näide, kus õpilase ja õpetaja tõlgendus $m h m h$-i tähendusest on erinev. Näide on katke 1. klassi eesti keele tunni osast, kus õpetaja palub õpilastel öelda, mis loom või lind nad tahaksid olla.

(16) ((1. klass eesti keel, õpetaja küsis, mis loom või lind lapsed olla tahaksid ja miks))

1. Õ: e 'Angela

2. . Angela: kui=ma=`oleksin `lind sis=ma oleksin `kalju `kotkas.

3. (.)

4. Õ: * miks. *

5. Angela: `sellepärast $=$ et na:d on (.) `nii ilu- > mulle= `meeldivad nende

'sulestik s.t nad on 6. äs- nad=on=ästi=ilsad `pruunid=ja `suured. <

7. Õ: * mhmh * ((õpetaja noogutab kätt tõstva Kristini suunas))

8. Angela: mulle `meeldivad `suured `linnud.

9. (.)

10. Kristin: kui=ma `oleksin `loom (...) `siis `ma `olekisin koer.

Näite 1. reas valib õpetaja vastama Angela ja saab temalt 2. ja 5.-6. reas vastuse. 7. reas reageerib õpetaja vastusele partikliga $m h m h$ ja suunab pilgu järgmisele õpilasele, Kristinile. See annab aluse tõlgendusele, et õpetaja kasutas $m h m h$-i vastuvõtuteatena ja algatas pilguga järgmist vastajat valides uue küsimussekventsi, kuna Angela vastas eeskujulikult esitatud küsimuse mõlemad pooled. Kuna $\mathrm{mhmh}$ aga ei ole piisavalt tugev piiritleja ning õpetaja verbaalselt uut sekventsi ei algatanud, andis see Angelale võimaluse tõlgendada õpetaja $m h m h$-i jätkajana ning oma vastust täpsustada.

- Vastupidiselt teoreetilisele eeldusele, et õpetaja kasutab tõenäoliselt minimaalset jätkajat rohkem õpilase kohta käivate küsimuste vastustele reageerides, näitas reaalse materjali analüüs vastupidist tulemust: õpetaja kasutas minimaalset jätkajat õpilase kohta käivate küsimuste vastustele reageerides kogu korpuses vaid 1 korral, teadmisi kontrollivatele küsimustele reageerides aga 19 korral, neist 14 juhul lisandus jätkajale eelmise vooru kinnitamise funktsioon. 


\subsection{Minimaalsed jätkamist taotlevad tagasisidekeelendid}

Minimaalsed jätkamist taotlevad tagasisidekeelendid esinesid pea kõigil juhtudel reaktsioonina teadmisi kontrolliva küsimuse vastusele. Vaid ühe õpilase kohta käiva küsimuse vastusele reageeris õpetaja mitteverbaalselt, noogutusega. See oli ka ainuke korpuses fikseeritud mitteverbaalne jätkav tagasiside. See tulemus ei kajasta mitteverbaalse jätkava tagaside reaalset hulka materjalis, vaid on seotud filmimise tehniliste puudujääkidega, kuna kogu õpetaja tegevus ei ole alati kaamera fookuses. Ülejäänud minimaalsed jätkavadtagasisidevahendid olid keelendid jaa, nii, veel ning vastuvõtukordus. Need (välja arvatud üks langeva intonatsiooniga hääldatud veel) olid hääldatud tõusva intonatsiooniga ja paiknesid positsioonis, kus küsimus eeldas pikemat või mitmeosalist vastust. Sellise tagasisidega annab õpetaja märku, et sama õpilane (mitte keegi teine) võib vastamisega jätkata ning ühtlasi kinnitab juba saadud vastuse osa.

(17) ((3. klass matemaatika))

1. Õ: `aa=korda `kolm `korrutised (...) on `Karolin.

2. Karolin: aa `öheksa=korda=`kolm=võrdub=`kakskend `seitse.

3. Õ: jaa?

4. (.)

5. Karolin: `kuus=korda=`kolm=võrdub `kaheksa `teist=ja

$`$ kaheksa $=$ korda $=` \operatorname{kolm}($.)

6. kakskend[\{neli\}]

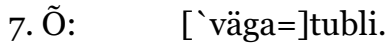

Näites (17) osutab õpetaja 3. reas öeldud tõusva intonatsiooniga jaa-ga, et Karolin loeks ette ka teised töövihikus olevad kolmega korrutised ning ühtlasi kinnitab ka juba saadud vastust.

\subsection{Järgmise vooru sisu suunav tagasiside}

Kui õpetaja soovib oma algatatud küsimussekventsi laiendada, on tal kaks põhimõttelist võimalust: esitada vastuse kohta täpsustav küsimus või algatada vastuse sisule ja/või vormile keskendatud parandussekvents.

Täpsustava küsimuse esitab õpetaja juhul, kui vastus on tema arvates ebapiisav või teema edasiarendamist väärt. Sekventsi lõpetava tagasiside annab õpetaja siis pärast õpilaselt saadud täpsustusi. Näites (18) esitab õpetaja täpsustava küsimuse õpilaselt reas 2 saadud vastuse kohta ning lõpetab küsimussekventsi hinnangulise reaktsiooniga sis on `tore.

(18) ((1. klass, eesti keel))

1. Õ: 'Arvi, ‘milline $=$ on `sinu uudis.

2. Arvi: $\{--\}$ sõitsin `rattaga $=$ ja `kukkusin `maha.

3. (...)

4. Õ: *'said=sa `väga haiget. *

5. Arvi: ei=`saand. ((Arvi raputab pead))

6. (.)

7. Õ: * sis=on `tore. * 


\section{8. (...) ((Tarmo tõstab kätt))}

9. Õ: `Tarmo?

Paranduse algatab õpetaja juhul, kui õpilase vastus oli vale või oli selles mingil põhjusel (näiteks kuulmis- või arusaamisprobleem) midagi parandamist-täpsustamist vajavat. Parandusalgatused on suunatud tekstis tahapoole, nad tegelevad juba väljaöeldud teksti toimetamisega. Vale või õpetaja arvates ebasobiva vastuse korral on õpetaja peamiseks tegutsemisstrateegiaks paranduse algatamine, mitte aga parandamine või negatiivse tagasiside andmine.

Analüüsitud korpuses oli kokku 82 õpetaja jaoks probleeme tekitanud vastust, neist 67 juhul algatas ta seepeale paranduse, andes probleemi lahendamise võimaluse probleemi allika väljaütlejale või mõnele teisele õpilasele. Ülejäänud 15 juhul parandas õpetaja probeeme tekitanud vastuse ise.

Näites (19) on õpetaja parandusalgatuse (real 4) põhjus õpilase vale vastus küsimusele aga `mida seal=pildil `jänestel kokku on `ka `veel `kolm.

(19) ((1. klass matemaatika))

1. Õ: aga `mida seal=pildil `jänestel kokku on `ka `veel `kolm.

2. (...)

3. Siim: kõrva.

\section{4. Õ: kas=`on ko- e:i `kõrvasid=on `rohkem, ko-`kõrvu=on} rohkem.

5. (...) ((osa lapsi tõstab kätt))

6. Õ: Andrus?

7. Andrus: nina.

8. Õ: < õige, > `kolm `jänest, `kolm `nina. (.) `vä:ga=tubli.

\section{Küsimussekventsi struktuur}

Tabel 3 visandab ülevaate õpetaja algatatud küsimussekventside ülesehitusest. Analüüsitavas materjalis leidus nii klassikalisi kolmikuid, nende laiendusi kui ka kahest komponendist koosnevaid küsimussekventse.

Tabel 3. Õpetaja algatatud küsimussekventsi struktuur

\begin{tabular}{|c|c|c|c|c|c|}
\hline \multicolumn{6}{|c|}{ Küsimussekventsi struktuur } \\
\hline $\begin{array}{l}\text { Õ: küsimus } \\
? \\
\text { L: vastus } \\
? \\
\text { Õ: tagasiside + } \\
\text { uue sekventsi } \\
\text { algatus }\end{array}$ & $\begin{array}{l}\text { Õ: küsimus } \\
? \\
\text { L: vastus } \\
? \\
\text { Õ: täpsustav küsimus/ } \\
\text { parandusalgatus } \\
? \\
\text { L: vastus } \\
? \\
\text { Õ: tagasiside+uue } \\
\text { sekventsi algatus }\end{array}$ & $\begin{array}{l}\text { Õ: küsi- } \\
\text { mus } \\
? \\
\text { L: vastus } \\
? \\
\text { Õ: uue } \\
\text { sekventsi } \\
\text { algatus }\end{array}$ & $\begin{array}{l}\text { Õ: küsimus } \\
? \\
\text { L: vastus } \\
? \\
\text { Õ: jätkaja } \\
? \\
\text { L: vastus } \\
? \\
\text { Õ:tagasiside+ } \\
\text { uue sekventsi } \\
\text { algatus }\end{array}$ & $\begin{array}{l}\text { Õ: küsimus } \\
? \\
\text { L: vastus } \\
? \\
\text { Õ: tagasiside } \\
? \\
\text { L: täpsustamine } \\
? \\
\text { Õ: tagasiside+ } \\
\text { uue sekventsi } \\
\text { algatus }\end{array}$ & $\begin{array}{l}\text { Vastuseta } \\
\text { küsimus }\end{array}$ \\
\hline 135 & 97 & $44^{1}$ & 20 & 4 & 7 \\
\hline Kokku & & & & & 310 \\
\hline
\end{tabular}

1 Tabelis märgitud 44 juhust 38-I on õpetaja kaamera fookuses, s.t on kindel, et õpetaja ei andnud vastusele mitte- 
Küsimussekventside vormi analüüs peegeldab, et õpetaja juhib kindlalt tunni sisu ja kulgu. Mis tahes õpilasepoolne algatuse/edasiarenduse võimalus on väike: kõik küsimussekventsid lõppevad õpetajapoolse uue küsimuse või tegevuse algatusega ${ }^{2}$, enamikku õpetaja algatatud küsimussekventsidest (84\%) suleb õpetaja tagasisidevoor. 31\% juhtudest eelneb õpetaja küsimussekventsi lõpetavale reaktsioonile vahesekvents, mis tegeleb eelmise vooru, s.o õpilase vooru parandamisega (parandusalgatused) või esitab õpetaja vastuse kohta täpsustavaid küsimusi. Vastaja jätkamist taotlevat tagasisidet, mis vastuse sisu kuidagi ei piiritle, annab õpetaja väga vähe (o,6\% juhtudest).

\section{Kokkuvõte ja arutelu}

Analüüs näitas, et algkoolitunnis juhib õpetaja kindlalt tunni käiku, õpilaste omapoose algatuse võimalus on minimaalne. See avaldus järgnevas.

- $\quad 84 \%$ õpetaja algatatud küsimussekventsidest sulges tagasisidevoor. Pärast tagasiside andmist esitas õpetaja kohe uue küsimuse või algatas uue tegevuse.

- Õpilase jätkamist taotlevat tagasisidet kasutas õpetaja 31\% juhtudest. Minimaalset jätkajat kasutas õpetaja äärmiselt vähe, vaid o,6\% juhtudest; pea kõigil juhtudel reaktsioonina teadmisi kontrolliva küsimuse vastusele kontekstis, kus eeldatav vastus oli mitmest osast koosnev. Ka n-ö vabama vestluse kontekstis, kus õpetaja küsis õpilase kohta, sulges õpetaja piiritleva tagasisidega sekventsi kas kohe pärast saadud vastust või pärast esitatud täpsustavat küsimust. Tulemus on üllatav, kuna õpilase kohta käivad küsimused olid suuremalt jaolt esitatud kontekstis, kus õpetaja pedagoogiline eesmärk oli arendada vestlust ja anda õpilastele rääkimise võimalus. Minimaalse jätkaja kasutamine selles kontekstis suurendaks õpilase iseseisva teemaarenduse võimalust. Selle formalistliku skeemi taga on tõenäoliselt õpilaste suur hulk klassis: tunni aeg on piiratud ja õpetaja peab andma võimaluse rääkida võimalikult paljudele. Piiritlevas funktsioonis tagasiside ja täpsustavad küsimused võimaldavad tunni sisu ja vooruvahetust kindlamini juhtida. Õpilased järgisid skeemi pea sajaprotsendiliselt: esines vaid 4 juhtu, kus õpilane jätkas vastamist pärast õpetaja sulgevat tagasisidet.

Koolitundide kolmikut on palju kritiseeritud, eriti võõrkeeleõpetuse kontekstis, peamiselt seetõttu, et õpetaja domineerib ja suhtlus erineb reaalsest vabast suulisest suhtlusest (vt näiteks Dinsmore 1985; Nunan 1987). Tegelikult on kolmikstruktuur traditsioonilises koolitunnis levinud kõigis vanuseastmetes ning sage ka eelkooliealise lapse ja vanema vestluses. Seega võib üldistada, et kolmikstruktuur on mis tahes õppimis- ja õpetamissüsteemis loomulik. Vestlusanalüütilise lähenemise järgi on koolitund sama "loomulik" kui argivestlus, koolitunnisuhtlust juhivad lihtsalt oma reeglid, koolitund on institutsionaalse suhtluse variant (Seedhouse 2004: 75). Kolmiku ülivaldav kasutus analüüsitud tundides peegeldab, et õpetaja ja õpilase rollijaotus on selles vanuseastmes rangelt asümmeetriline. Kolmikstruktuur võimaldab oppetajal õpilase vastust hinnata ning tunni käiku ja vooruvahetust reguleerida.

Õpetaja tagasiside on paindlik ja hulga tähendusnüanssidega nähtus, tagasiside konkreetne tähendus ja funktsioon selgub reaalset kasutuskonteksti analüüsides.

${ }^{2}$ Möödaminnes võiks mainida, et õpilase esitatud küsimusi oli vaadeldud tundides väga vähe (7\% küsimustest). 
Teadmisi kontrollivate küsimuste vastustele kaldub lisanduma kinnituse, õpilase kohta käivate küsimuste vastustele hinnangu tähendus. Tagasiside kinnituse tugevus on astmeline, skaala ühes otsas on neutraalsed info vastuvõtuteated, millel kinnituse tähendus puudub, teises otsas keelend õige. Näiteks võib tagasisidena teadmisi kontrolliva küsimuse vastusele, millega õpetaja rahule ei jäänud, kasutada neutraalset ja/või piiritlevat vastuvõtuteadet, millel kinnituse tähendus puudub, ning anda "tugevama" kinnitava tagasiside alles pärast soovitud vastuse saamist.

Uurimus visandab esimese, üldistava ülevaate õpetaja algatatud küsimussekventside struktuurist ja õpetaja tagasiside funktsioonist. Autori edasine eesmärk on arvestada küsimusskventside analüüsil täpsemat konteksti. Selle idee taga on teoreetiline eeldus, et õpetaja pedagoogiline eesmärk muutub tunni eri osades ja sellest võib sõltuda ka küsimussekventside struktuur ja tagasiside funktsioon. Erinevad on näiteks kontekst, kus õpetaja ootab oma küsimusele täpset vastust (nt keeletunnis kindlat sõnavormi, matemaatikatunnis arvutusülesande vastust); vestluse arendamise kontekst, kus õpetaja eesmärk on panna lapsed rääkima; uute teadmiste omandamise kontekst, kus õpetaja esitab küll tedmisi kontrollivaid küsimusi, kuid õiged vastused esitatud küsimustele ei pea olema vormilt ja sisult sedavõrd täpsed kui näiteks matemaatikatunni arvutusülesannete puhul. Huvitavaid tulemusi võiks pakkuda ka küsimussekventside võrdlus klasside kaupa. Samuti on tulevase töö seisukohalt oluline parandada filmimise tehnikat, et jäädvustada analüüsi seisukohalt väga oluline mitteverbaalne suhtlus.

Loodetavasti annavad juba saadud ja tulevikus täpsustuvad teadmised tagasiside kohta õpetajale uusi võimalusi rakendada keelelisi/suhtluslikke vahendeid oma pedagoogiliste eesmärkide teenistusse..

\section{Kirjandus}

Dinsmore, David 1985. Waiting for Godot in the EFL classroom. - ELT Journal 39, 225234.

Drew, Paul; Heritage, John 1992. Analyzing talk at work. - Paul Drew, John Heritage (Eds.). Talk at Work. Interaction in Institutional Settings. Cambridge University Press, $3-65$.

Hennoste, Tiit 2000a. Sissejuhatus suulisesse eesti keelde VI. Lausung suulises kõnes I. - Akadeemia 10, 2223-2254.

Hennoste, Tiit 200ob. Sissejuhatus suulisesse eesti keelde IV. Suulise keele erisõnavara III. - Akadeemia 8, 1773-1806.

Hennoste, Tiit; Rääbis, Andriela 2004. Dialoogiaktid eesti infodialoogides: tüpoloogia ja analüüs. Tartu Ülikool, arvutiteaduse instituut. Tartu: Tartu Ülikooli Kirjastus.

Hutchby, Ian; Wooffitt, Robin 1998. Conversation Analysis. Principles, Practices and Applications. Cambridge: Polity Press.

Kasterpalu, Riina 2005. Partiklid jah, jaa ning jajaa naaberpaari järelliikmena müügiläbirääkimistes. - Keel ja Kirjandus 12, 996-1000.

Keevallik, Leelo 200o. Keelendid et ja nii et vestluses. - Keel ja Kirjandus 5, 344-358.

Keevallik, Leelo 2003. From Interaction to Gammar. Estonian Finite Verb Forms in Conversation. Acta Universitatis Upsaliensis. Studia Uralica Upsaliensia 34. Uppsala.

Mehan, Hugh 1985. The Structure of Classroom Discourse. - Teun A. van Dijk (Ed.). Handbook of Discourse Analysis. Vol. 3. Discourse and Dialogue. London: Academic Press, 119-131. 
Nunan, David 1987. Communicative Language Teaching: Making it work. - ELT Journal 41 (2), 136-145.

Pajusalu, Renate 1999. Deiktikud eesti keeles. Dissertationes Philologiae Estonicae Univesitatis Tartuensis 8. Tartu: Tartu Ülikooli Kirjastus.

Sacks, Harvey 1992. Lectures on Conversation. Gail Jefferson (Ed.). Cambridge-Oxford: Blackwell.

Seedhouse, Paul 2004. The Interactional Architecture of the Language Classroom: A Conversation Analysis Perspective. Blackwell Publishing.

Sinclair, John; Coulthard, Malcolm 1975. Toward an Analysis of Discourse. Oxford: Oxford University Press.

Krista Strandsoni (Tartu Ülikool) uurimisvaldkonnad on suuline keel, parandused suulises keeles, infodialoogide struktuur, koolitunnisuhtlus.

krista.strandson@ut.ee 


\section{TEACHER'S FEEDBACK TO STUDENTS' ANSWERS IN PRIMARY SCHOOL LESSONS}

\section{Krista Strandson}

University of Tartu

The objective of the paper is to analyse teacher's feedback to students' answers and to outline the structure of teacher-initiated question sequences in Estonian primary school lessons. The teacher's feedback is analysed from two points of view. First, how is the teacher's feedback related to the content of the question, i.e. does the teacher's feedback to the answer to a question aimed to check a pupil's knowledge differ from her feedback to theanswer to a question about the pupil? Second, what is the function of the teacher's feedback; how does the teacher's feedback determine the course of further interaction? The survey is based on a transcribed collection of video-recordings (280 min in total) of Estonian and mathematics lessons that took place in 1st-3rd forms at a school in Tartu, Estonia. The main results of the analysis are as follows. The teacher leads the course of the lesson with utmost resolution. The possibility of student-initiated activity is minimal. This is illustrated by the following facts. (1) The teacher's feedback terminating the question sequence is predominant irrespective of the content of the questions. The majority of the question sequences initiated by the teacher constitute a triadic structure (questionanswer-feedback) even if the teacher's pedagogical aim is to develop a conversation. (2) The teacher uses next to no minimal continuers as feedback. The majority of the teacher's feedback encouraging the pupils to continue are specifying questions about the answer just given.

Keywords: conversation analysis, classroom interaction, question sequences, reaction to the answer, Estonian 